Research Article

\title{
A study of potential drug-drug interactions among critically ill patients at a tertiary care hospital
}

\author{
Manjeeta Gupta*, Aparna S. Chincholkar, Ranjit J. Wagh, Nidhi Maheshwari, \\ Waseem Siddiqui
}

Department of Pharmacology, MIMER Medical College, Talegaon Dabhade, Pune, 410507, Maharashtra, India

Received: 09 June 2016 Accepted: 15 June 2016

*Correspondence to: Dr. Manjeeta Gupta, Email: guptamanjeeta@ gmail.com

Copyright: (C) the author(s), publisher and licensee Medip Academy. This is an openaccess article distributed under the terms of the Creative Commons Attribution NonCommercial License, which permits unrestricted noncommercial use, distribution, and reproduction in any medium, provided the original work is properly cited.

\begin{abstract}
Background: Drug interaction is said to occur when presence of one drug affects the activity of another drug when both are administered together. This action can be synergistic or antagonistic. The objective was to study the prevalence of potential drug-drug interactions (pDDI), their severity, clinical significance, and their association with patient characteristics in intensive care unit (ICU) at a tertiary care hospital.

Methods: A prospective, observational study was conducted in ICU patients for a period of 3 months to assess the pDDI using Medscape drug checker software and Lexi-Comp, inc. version: 2.7.5. drug interact android mobile application.

Results: A total of 183 subjects were included in the study with a prevalence of $76.50 \%$ pDDI occurring in patients, majority of which were suffering from cardiovascular conditions $(26.23 \%)$. In those with hospital stay more than five days, $92 \%$ had pDDI. There were 229 potentially interacting drug pairs with corticosteroids, aspirin, beta blockers, and diuretics being commonly involved in pDDI. A total of 2336 interactions were observed with an occurrence rate of 12.76 DDI per patient. Severity was moderate in $64 \%$, interaction mechanism was pharmacodynamic in $72.49 \%$ and risk rating category was $\mathrm{C}$ in $77.1 \%$ of the study population.

Conclusions: The present study showed high concomitant administration of potentially interacting drugs. The prevalence confirmed the association of age and polypharmacy. Vigilant prescribing approach is needed to prevent hazardous outcomes of pDDI.
\end{abstract}

Keywords: Potential drug interaction, Intensive care, Drug interaction software, Patient safety

\section{INTRODUCTION}

Drugs are used to achieve beneficial therapeutic effects, but they can also lead to many undesirable consequences like reduced, null or increased drug effect. ${ }^{1}$ This can be due to interactions of various drugs with each other when administered together. ${ }^{2}$

In primary healthcare, $9.2 \%$ to $78.8 \%$ of patients are reported to be at risk of a potential drug-drug interactions (pDDI) due to concomitant administration of drugs. ${ }^{3}$ Intensive care unit (ICU) patients are at greater risk. For experiencing adverse events as they are more susceptible due to their severity of illness, number of medications prescribed and long duration of hospital stay. ${ }^{4}$ A study done in ICU showed that risk of an adverse event increases by approximately $6 \%$ per day. ${ }^{4}$

Often pDDI go unnoticed in these patients as their symptoms due to disease mask the symptoms due to DDI. DDI pose significant challenge to health care providers and may affect morbidity, mortality and patient's quality of life. ${ }^{5}$ It is therefore very important to closely monitor these patients and train the health care professionals for the same. ${ }^{6}$ Interventions aimed at reducing pDDI are likely to be more effective, if the incidence and pattern of pDDI are determined accurately before their occurence. ${ }^{7}$

Since no study was previously done in rural population of Maval district, Pune addressing this issue, the present 
study was undertaken to make practitioners aware of the importance of pDDI. The objective was to study the prevalence, risk and severity of pDDI and suspected causative drugs/commonly involved drugs in critically ill patients.

\section{METHODS}

A prospective study was done at Bahusaheb Sardesai Rural Tertiary care Hospital (BSRTH) and Maharashtra Institute of Medical Education and Research (MIMER) Medical College Talegaon Dabhade, Pune, India. The study was for a period of 3 months (July 2014 to September 2014). Institutional Ethics Committee approval was taken before commencing the study.

Case records of all the patients above 18 years, admitted in ICU for more than 24 hours were included in the study. Data was collected on the case record form which included details about patients' demographic, provisional diagnosis, prescription details, and number of days in hospital and analysed for pDDI by using drug interaction softwares, Medscape drug checker software and LexiComp, inc. version: 2.7.5. ${ }^{8,9}$ Drug interact android mobile application, product of Wolters Kluwer Health (Philadelphia, PA). ${ }^{1,2}$

pDDI were classified according to pharmacodynamic and pharmacokinetic properties and their severity using Medscape drug checker software (Table 1) and on the basis of risk involved by Lexi Comp drug interact android application (Table 2). The diagnosis of the study patients was classified according to International Classification of Disease (ICD-10) and drugs were classified according to anatomical therapeutic chemical classification system (ATC). ${ }^{10,11}$

\section{Table 1: Severity scale.}

\begin{tabular}{|ll|}
\hline Major & $\begin{array}{l}\text { Effects may result in death, } \\
\text { hospitalization, permanent injury, or } \\
\text { therapeutic failure }\end{array}$ \\
\hline Moderate & $\begin{array}{l}\text { Medical intervention needed to treat } \\
\text { effects; effects do not meet criteria for } \\
\text { major }\end{array}$ \\
\hline Minor & $\begin{array}{l}\text { Effects would be considered tolerable in } \\
\text { most cases; no need for medical } \\
\text { intervention }\end{array}$ \\
\hline
\end{tabular}

\section{Statistical analysis}

Results are expressed as percentage for age, gender, diagnosis, length of ICU stay, number of drugs prescribed, severity and risk involved. Chi-square test was done to study the association of age and number of drugs prescribed with pDDI.
Table 2: Risk rating.

\begin{tabular}{|c|c|c|}
\hline $\begin{array}{l}\text { Risk } \\
\text { rating }\end{array}$ & Action & Description \\
\hline A & $\begin{array}{l}\text { No known } \\
\text { interaction }\end{array}$ & $\begin{array}{l}\text { Data have not demonstrated } \\
\text { either pharmacodynamic or } \\
\text { pharmacokinetic interactions }\end{array}$ \\
\hline B & $\begin{array}{l}\text { No action } \\
\text { needed }\end{array}$ & $\begin{array}{l}\text { May interact with each other, } \\
\text { but there is no evidence of } \\
\text { clinical concern }\end{array}$ \\
\hline $\mathrm{C}$ & $\begin{array}{l}\text { Monitor } \\
\text { therapy }\end{array}$ & $\begin{array}{l}\text { The benefits of concomitant } \\
\text { use of these two medications } \\
\text { usually outweigh the risks }\end{array}$ \\
\hline $\mathrm{D}$ & $\begin{array}{l}\text { Therapy } \\
\text { modification }\end{array}$ & $\begin{array}{l}\text { Assess whether the benefits of } \\
\text { concomitant therapy outweigh } \\
\text { the risks or not }\end{array}$ \\
\hline$X$ & $\begin{array}{l}\text { Avoid } \\
\text { combination }\end{array}$ & $\begin{array}{l}\text { The risks associated with } \\
\text { concomitant use outweigh the } \\
\text { benefits }\end{array}$ \\
\hline
\end{tabular}

\section{RESULTS}

Out of 227 patients admitted in the ICU, 183 patients fulfilled the criteria of admission for more than 24 hours in the ICU and were included in the study. Out of 183 patients included in the study, 67.2\% were males (Table 3). 140 out of 183 study populations (76.50\%) were exposed to pDDI with an average of $12.76 \mathrm{pDDI}$ occurring per patient. In patients, 18-45 years of age $58.62 \%$ had pDDI, between 46-65 years and above 65 years had $85.71 \%$ and $96.15 \%$ pDDI respectively which was statistically significant (Figure 1).

Table 3: Demographic details of study population.

\begin{tabular}{|llll|}
\hline Age & Gender & $\mathbf{N}($ Total=183) & $\begin{array}{l}\text { \% of total study } \\
\text { population }\end{array}$ \\
\hline \multirow{2}{*}{$18-25$} & $\mathrm{M}$ & 15 & 8.2 \\
\cline { 2 - 4 } & $\mathrm{F}$ & 21 & 11.48 \\
\hline \multirow{2}{*}{$26-45$} & $\mathrm{M}$ & 45 & 24.59 \\
\cline { 2 - 4 } & $\mathrm{F}$ & 6 & 3.38 \\
\hline $46-65$ & $\mathrm{M}$ & 27 & 14.75 \\
\cline { 2 - 4 } & $\mathrm{F}$ & 17 & 9.29 \\
\hline $\begin{array}{l}\text { Above } \\
65\end{array}$ & $\mathrm{M}$ & 36 & 20 \\
\cline { 2 - 4 } & $\mathrm{F}$ & 16 & 8.89 \\
\hline
\end{tabular}

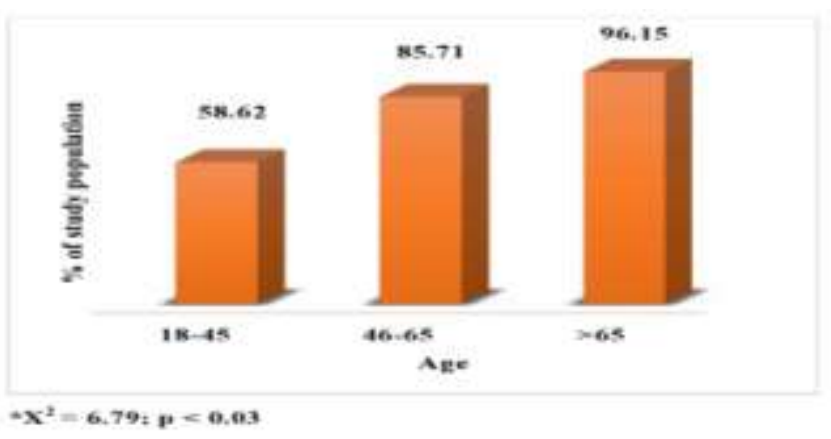

Figure 1: Age and pDDIs. 
A total of 1510 drugs were administered to the study patients, average of 8.25 drugs per patient. About $73.84 \%$ patients received medicines parenterally and in $26.16 \%$, drugs were administered through other routes.

The most common system involved in diagnosis was cardiovascular system $(26.23 \%)$ and poisoning $(26.23 \%)$ followed by central nervous system (14.44\%) and respiratory system $(14.44 \%)$ respectively. The major drug categories found to be interacting were cardiovascular drugs, antimicrobials, drugs belonging to alimentary tract and metabolism category, and drugs given for blood disorders. Drugs under alimentary tract and metabolism included antidiabetic agents $(1.88 \%)$ and gastrointestinal tract drugs $(6.25 \%)$. Cardiovascular drugs consisted of antihypertensive (23.37\%) and diuretics (7.28\%). Major antimicrobials causing pDDI in this study were penicillins (0.94\%), cephalosporins (2.74), macrolides (0.34\%), aminoglycosides $(3.25 \%)$, fluoroquinolones $(1.71 \%)$, tetracycline's $(0.68 \%)$.

There were 229 types of drug pairs found to interact at least one time. Aspirin plus enoxaparin, aspirin plus beta blocker, corticosteroid plus metronidazole, and clopidogrel plus pantoprazole, were the drug pairs causing maximum interactions (Table 4).

Table 4: Common DDI pairs of drugs.

\begin{tabular}{|llllll|}
\hline pDDI pairs & pDDI & Severity & Risk & n=229 & \% \\
\hline Aspirin+enoxaparin & Enhance anti-coagulant effect & Moderate & C & 38 & 16.59 \\
\hline Aspirin+beta blocker & Both increase serum potassium & Major & C & 30 & 13.10 \\
\hline Corticosteroid+metronidazole & $\begin{array}{l}\text { Metronidazole increases serum concentration of } \\
\text { corticosteroid by affecting CYP3A4 enzyme }\end{array}$ & Major & C & 28 & 12.23 \\
\hline Clopidogrel+pantoprazole & $\begin{array}{l}\text { Pantoprazole decreases serum concentration of } \\
\text { active metabolites of clopidogrel }\end{array}$ & Major & D & 28 & 12.23 \\
\hline Corticosteroid+furosemide & $\begin{array}{l}\text { Corticosteroids enhances hypokalaemia effect } \\
\text { of furosemide }\end{array}$ & Moderate & C & 26 & 11.35 \\
\hline Corticosteroid+aspirin & $\begin{array}{l}\text { Aspirin enhances toxicity of corticosteroids. } \\
\text { Corticosteroids decrease serum concentration of } \\
\text { aspirin }\end{array}$ & Moderate & C & 24 & 11.05 \\
\hline Corticosteroid+atorvastatin & $\begin{array}{l}\text { Atorvastatin increase the level or effect of } \\
\text { corticosteroid by P-glycoprotein (MDR1) efflux } \\
\text { transporter }\end{array}$ & Moderate & C & 24 & 10.48 \\
\hline Aspirin+clopidogrel & Enhance anti-platelet effect & Moderate & C & 24 & 10.48 \\
\hline Cephalosporin+furosemide & Increase risk of nephrotoxicity & Minor & B & 24 & 10.48 \\
\hline Aspirin+furosemide & $\begin{array}{l}\text { Aspirin diminishes diuretic effect } \\
\text { Furosemide increases serum concentration of } \\
\text { aspirin }\end{array}$ & Moderate & C & 22 & 9.61 \\
\hline Enoxaparin+clopidogrel & Enhance anti-coagulant effect & Moderate & C & 22 & 9.61 \\
\hline
\end{tabular}

All patients who were given more than 10 drugs showed pDDI, followed by $37 \%$ patients in group with number of drugs 6 to 10 (Figure 2).

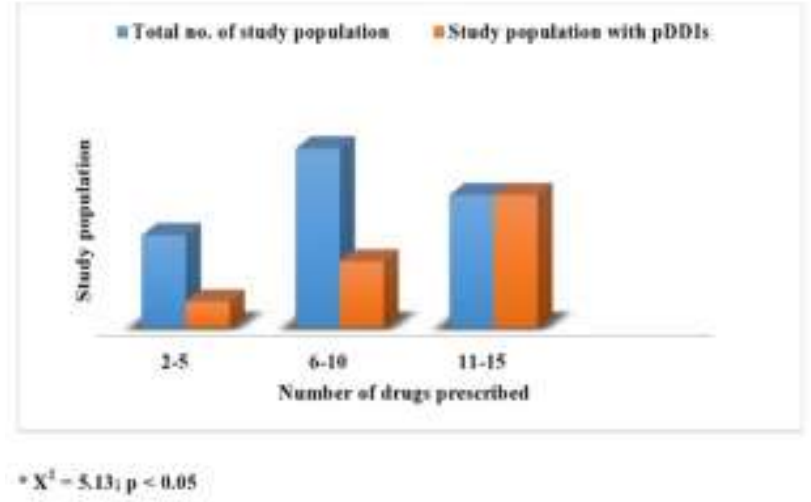

Figure 2: Polypharmacy and pDDIs.
Maximum number of drugs prescribed was 17. Statistical correlation was seen between number of drugs prescribed and pDDI. In patients admitted for more than 5 days the occurrence rate of pDDI was $92 \%$ (Figure 3 ).

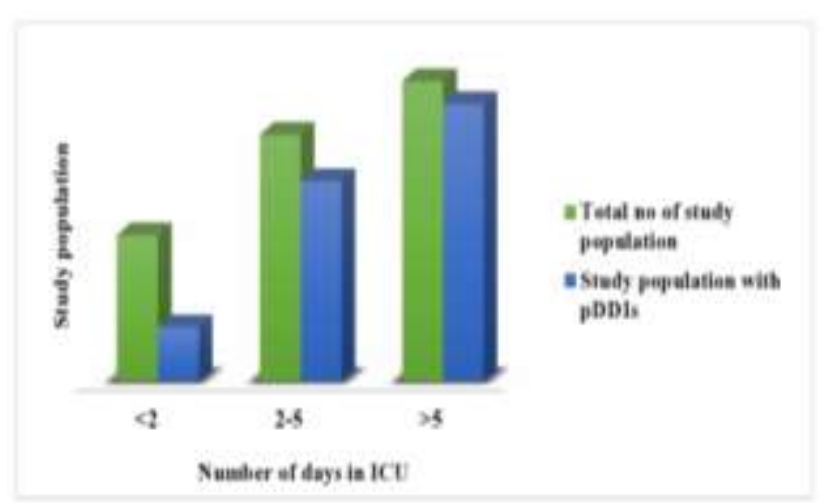

Figure 3: Number of days in ICU and pDDIs. 
According to Medscape drug checker software severity most of the pDDI fell in the moderate category $(64.63 \%)$ (Figure 4). In terms of the level of clinical significance, the majority of pDDI were categorised as type-C $(60.26 \%)$ (Figure 5). Overall, pharmacodynamics-related pDDI were more common (57.87\%) than pharmacokinetics - related pDDI $(41.85 \%)$.

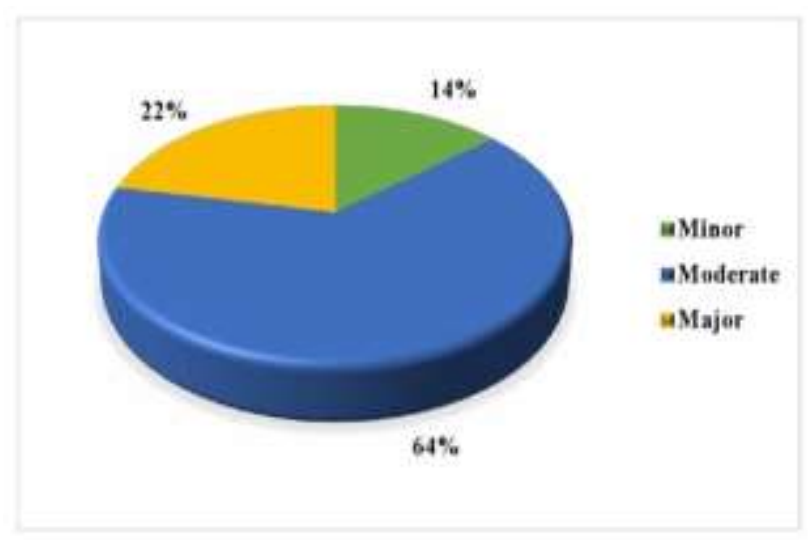

Figure 4: Severity of pDDIs.

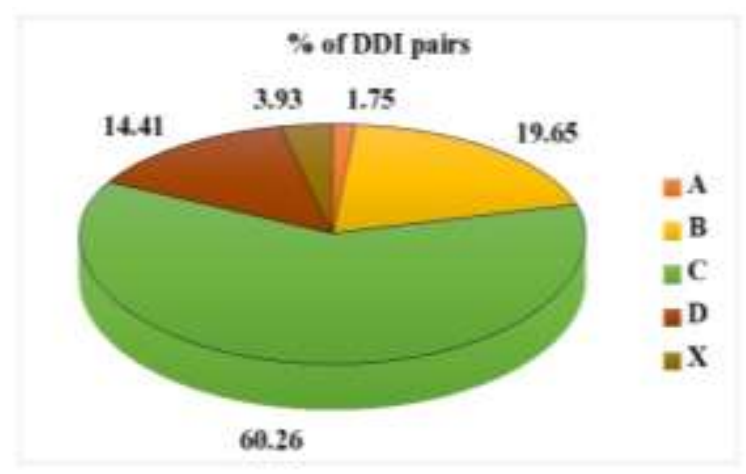

Figure 5: Risk of pDDIs.

\section{DISCUSSION}

Prevalence of pDDI in this study was $76.5 \%$. In an Indian study conducted in hypertensive patients the prevalence was found to be $71.50 \% .^{9}$ Most of the studies had female preponderance which is inconsistent with the present study. ${ }^{8,12,13}$ However there was no significant gender difference associated with pDDI seen with this study. The difference in the results can be due to different geographical regions in the study.

A relationship between age and pDDI was reported in multiple studies which is in concordance with the present study. $^{5-7,9,12,15-17}$ Hence, we can say that pDDI are more common in elderly probably due to age related physiological, pharmacokinetic and pharmacodynamic changes.

Most of the studies have shown a direct relationship between pDDI and increase in number of drugs prescribed. ${ }^{1-3,5-9,12-18}$ The present study also shows a statistical association between polypharmacy and number of pDDI.

pDDI have a direct relation with duration of hospital stay. ${ }^{1}$ Patients with duration of stay more than five days in the ICU were seen to be at a greater risk of developing pDDI. This can be correlated to greater number of drugs to which patients are exposed to during their prolonged stay.

Our study was found to be similar to various studies in which major drug categories found to be interacting were cardiovascular drugs. ${ }^{5,8,15-17}$ Since majority of the patients suffered from cardiovascular disorder and the number of drugs from cardiovascular system were more it can be the reason for the high incidence of pDDI occurring in this group.

More than $60 \%$ interactions were of moderate severity and were clinically insignificant. This was consistent with other studies in which severity range was from $64 \%-70.4 \%$ in moderate category. ${ }^{1,8,10,12,15,18}$ In risk rating, category $\mathrm{C}$ was most common which required monitoring of therapy and was found to be similar to a study done by Doubova et al. ${ }^{3}$ According to mechanism of interactions, most of the pDDI were pharmacodynamic which was also seen with studies done in India using Medscape drug checker software. 9,16

This study is among the few studies done in India for assessing the prevalence of pDDI using drug interaction softwares'. This study had a few limitations. It was based mainly on the information obtained from Medscape drug checker software and Lexi Comp drug interact which provides only a 'potential' estimate of DDI occurrence. The study did not consider the synergistic mechanisms associated with various drug pairs as well as interactions with other herbal or vitamin supplements. Limited time duration and small sample size without any intervention component and lack of clinical correlation between pDDI due to lack of resources were other limitations of the study.

\section{CONCLUSION}

The study shows a high prevalence of pDDI that can occur in ICU patients. The findings show statistical association of pDDI with age and polypharmacy.

\section{Recommendations}

Use of computer assisted drug interaction softwares' before prescribing drugs can serve as an important tool in identifying these pDDI which can help us detect and prevent drug interactions from occurring especially in high risk patients. However, more studies are warranted to further establish these results. 


\section{ACKNOWLEDGEMENTS}

Author would like to thank BSRTRH and MIMER Medical College Talegaon, India, HOD of Medicine, Dr. Dilip Bhoge for helping with the collection of data.

Funding: No funding sources Conflict of interest: None declared

Ethical approval: The study was approved by the Institutional Ethics Committee

\section{REFERENCES}

1. Hasan SS, Lim KN, Anwar M, Sathvik BS, Ahmadi $\mathrm{K}$, Yuan AW, et al. Impact of pharmacists' intervention on identification and management of drug-drug interactions in an intensive care setting. Singapore Med J. 2012;53(8):526-31.

2. Abideen S, Vivekanandan K, Mishra P. Assessment of prevalence of potential drug-drug interactions in medical intensive care unit of a tertiary care hospital in India. Asian J Pharm Clin Res. 2015;8(1):125-30.

3. Doubova SV, Morales HR, Arreola LT, Ortega MS. Potential drug-drug and drug-disease interactions in prescriptions for ambulatory patients over 50 years of age in family medicine clinics in Mexico city. BMC Health Serv Res. 2007;7:147.

4. Moyen E, Camire E, Stelfox HT. Clinical review: medication errors in critical care. Crit Care. 2008;12(2):208.

5. Kumar MA, Nizar A, Shailaja K, Jayasutha J, Ramasamy C. A study on prescribing pattern and potential drug-drug interactions in type 2 diabetes mellitus (inpatients) in a tertiary care teaching hospital. Der Pharmacia Lettre. 2011;3(4):13-9.

6. Ahmadizar F, Soleymani F, Abdollahi M. Study of drug interactions in prescriptions of general practitioners and specialists in Iran 2007-2009. Iran J Pharm Res. 2011;10(4):921-31.

7. Nabovati E, Arki HV, Taherzadeh Z, Hasibian MR, Hanna AA, Eslami S, et al. Drug-drug interactions in inpatient and outpatient settings in Iran: a systematic review of the literature. Daru. 2014;22(1):52.

8. Bleich GW, Bleich A, Chiamulera P, Sanches AC, Schneider DS, Teixeira JV, et al. Frequency of potential interactions between drugs in medical prescriptions in a city in southern Brazil. Sao Paulo Med J. 2009;127(4):206-10.
9. Kothari N, Ganguly B. Potential drug-drug interactions among medications prescribed to hypertensive patients. J Clin Diagn Res. 2014;8(11):1-4.

10. International Statistical Classification of Diseases and Related Health Problems 10th Revision (ICD10)-2015-WHO Version for 2015. Available from: http:// apps.who.int/classifications/icd10/browse/2015/en. Accessed in 20 August 2015.

11. World Health Organization. The anatomical therapeutic chemical classification system with defined daily doses (ATC/DDD). Available at: http://www.who.int/classifications/atcddd/en/. Accessed on 28 August 2015.

12. Secoli SR, Figueras A, Lebrao ML, Lima FD, Santos JL. Risk of potential drug-drug interactions among Brazilian elderly: a population based, cross sectional study. Drugs and Aging. 2010;27(9):75970.

13. Pirmohamed M, James S, Meakin S, Green C, Scott AK, Walley TJ, et al. Adverse drug reactions as cause of admission to hospital: prospective analysis of $18 \quad 820$ patients. British Med J. 2004;329(7456):15-9.

14. Rafi MS, Naqvi SB, Khan MU, Fayyaz M, Ashraf N, Khan MA, et al. Evaluation of potential drugdrug interactions with antidepressants in two tertiary care hospitals. J Clinic Diagn Res. 2015;9(7):5-8.

15. Teixeira JV, Crozatti MT, Santos CA, Lieber NS. Potential drug-drug interactions in prescriptions to patients over 45 years of age in primary care, southern Brazil. Public Lib Sci One. 2012;7(10):1-6.

16. Bista D, Saha A, Mishra P, Palaian S, Shankar PR. Impact of educational intervention on the pattern and incidence of potential drug-drug interactions in Nepal. Pharm Pract (Granada). 2009;7(4):242-7.

17. Nobili A, Pasina L, Tettamanti M, Lucca U, Riva E, Marzona I. Potentially severe drug interactions in elderly outpatients: results of an observational study of an administrative prescription database. J Clinic Pharm Therap. 2009;34(4):377-86.

18. Ray S, Pramanik J, Bhattacharyya M, Todi S. Prospective observational evaluation of incidences and implications of drug-drug interactions induced adverse drug reactions in critically ill patients. Indian J Pharm Sci. 2010;72(6):787-92.

Cite this article as: Gupta M, Chincholkar AS, Wagh RJ, Maheshwari N, Siddiqui W. A study of potential drug-drug interactions among critically ill patients at a tertiary care hospital. Int J Basic Clin Pharmacol 2016:5:1281-5. 